\title{
Regulators of G-Protein Signaling (RGS) Proteins Promote Receptor Coupling to G-Protein-Coupled Inwardly Rectifying Potassium (GIRK) Channels
}

\author{
Kylie B. McPherson, ${ }^{1}$ Emily R. Leff, ${ }^{1}{ }^{-}$Ming-hua Li, ${ }^{1}$ Claire Meurice, ${ }^{2}$ Sherrica Tai, ${ }^{2,3}$ John R. Traynor, ${ }^{2,3}$ \\ and $\odot$ Susan L. Ingram ${ }^{1}$ \\ ${ }^{1}$ Department of Neurological Surgery, Oregon Health \& Science University, Portland, Oregon 97239, ${ }^{2}$ Department of Pharmacology, and ${ }^{3}$ Edward F Domino \\ Research Center, University of Michigan, Ann Arbor, Michigan 48109
}

\begin{abstract}
Regulators of G-protein signaling (RGS) proteins negatively modulate presynaptic $\mu$-opioid receptor inhibition of GABA release in the ventrolateral periaqueductal gray (vlPAG). Paradoxically, we find that G-protein-coupled receptor (GPCR) activation of G-protein-gated inwardly rectifying $\mathrm{K}^{+}$channels (GIRKs) in the vlPAG is reduced in an agonist- and receptor-dependent manner in transgenic knock-in mice of either sex expressing mutant RGS-insensitive $\mathrm{G} \alpha$ o proteins. $\mu$-Opioid receptor agonist activation of GIRK currents was reduced for DAMGO and fentanyl but not for $\left[\mathrm{Met}^{5}\right]$-enkephalin acetate salt hydrate (ME) in the RGS-insensitive heterozygous (Het) mice compared with wild-type mice. The $\mathrm{GABA}_{\mathrm{B}}$ agonist baclofen-induced GIRK currents were also reduced in the Het mice. We confirmed the role of $\mathrm{G} \alpha$ o proteins in $\mu$-opioid receptor and $\mathrm{GABA}_{\mathrm{B}}$ receptor signaling pathways in wild-type mice using myristoylated peptide inhibitors of $\mathrm{G}_{\alpha 0_{1}}$ and $\mathrm{G} \alpha \mathrm{i}_{1-3}$. The results using these inhibitors indicate that receptor activation of GIRK channels is dependent on the preference of the agonist-stimulated receptor for $\mathrm{G} \alpha \mathrm{o}$ versus that for $\mathrm{G} \alpha \mathrm{i}$. DAMGO and fentanyl-mediated GIRK currents were reduced in the presence of the $\mathrm{G} \alpha 0_{1}$ inhibitor, but not the $\mathrm{G} \alpha \mathrm{i}_{1-3}$ inhibitors. In contrast, the $\mathrm{G} \alpha \mathrm{o}_{1}$ peptide inhibitor did not affect $\mathrm{ME}$ activation of GIRK currents, which is consistent with results in the Het mice, but the $\mathrm{G} \alpha \mathrm{i}_{1-3}$ inhibitors significantly reduced ME-mediated GIRK currents. Finally, the reduction in GIRK activation in the Het mice plays a role in opioid- and baclofenmediated spinal antinociception, but not supraspinal antinociception. Thus, our studies indicate that RGS proteins have multiple mechanisms of modulating GPCR signaling that produce negative and positive regulation of signaling depending on the effector.
\end{abstract}

Key words: analgesia; descending pain pathway; $\mathrm{GABA}_{\mathrm{B}}$ receptor; opioids; periqueductal gray; RGS proteins

Significance Statement

Regulators of G-protein signaling (RGS) proteins positively modulate GPCR coupling to GIRKs, and this coupling is critical for opioid- and baclofen-mediated spinal antinociception, whereas $\mu$-opioid receptor-mediated supraspinal antinociception depends on presynaptic inhibition that is negatively regulated by RGS proteins. The identification of these opposite roles for RGS proteins has implications for signaling via other GPCRs.

\section{Introduction}

Morphine and other opioids elicit antinociception through the activation of a specific set of G-protein-coupled receptors

\footnotetext{
Received Feb. 23, 2018; revised July 31, 2018; accepted Aug. 20, 2018.

Author contributions: J.R.T. and S.L.I. designed research; K.B.M., E.R.L., M.-h.L., C.M., and S.T. performed research; K.B.M., M.-h.L., C.M., S.T., J.R.T., and S.L.I. analyzed data; S.L.I. wrote the paper.

The studies were funded by National Institutes of Health Grants R01-DA-035316 (to J.R.T.) and T32-NS-007466

(to K.B.M. and E.R.L.). We thank Katherine L. Suchland and Janet D. Lowe for technical support.

The authors declare no competing financial interests.

Correspondence should be addressed to Dr. Susan L. Ingram, Department of Neurological Surgery, Oregon Health \& Science University, 3181 SW Sam Jackson Park Road, Portland, OR 97239. E-mail: Ingrams@ohsu.edu.

C. Meurice's present address: Pharmacology Graduate Group, Perelman School of Medicine, University of Pennsylvania, Philadelphia, PA 19104.
}

(GPCRs)—the $\mu$-opioid receptors (Matthes et al., 1996). However, $\mu$-opioid receptor agonists also mediate adverse side effects, including tolerance, dependence, and respiratory depression (Williams et al., 2013), decreasing the therapeutic value of these agonists for pain. A focus of current research has been on identifying $\mu$-opioid receptor signaling pathways and/or circuits that mediate opioid-induced antinociception with the hope that side effects are the result of separate circuits. Several $\mu$-opioid receptor agonists exhibit functional selectivity based on their ability to promote biased signaling via G-proteins with limited recruit- 
ment of $\beta$-arrestin (Bohn et al., 1999; Raehal et al., 2005, 2011; DeWire et al., 2013; Manglik et al., 2016; Koblish et al., 2017). The focus on biased signaling as a novel approach for developing $\mu$-opioid receptor agonists that are efficacious for pain relief without serious side effects highlights the importance of understanding G-protein signaling pathways.

Agonists for the $\mu$-opioid receptor promote the exchange of GTP for GDP on inactive G $\alpha$ subunits. This allows activation of the complex and subsequent dissociation of $\mathrm{G} \alpha$ and $\mathrm{G} \beta \gamma$ subunits, both of which signal through multiple downstream effector proteins. Termination of G-protein subunit signaling is facilitated by regulators of G-protein signaling (RGS), GTPaseaccelerating proteins (GAPs) that promote the hydrolysis of GTP on the active $\mathrm{G} \alpha$ subunits, re-establishing their affinity for $\mathrm{G} \beta \gamma$ and decreasing downstream signaling to coupled effector pathways (Traynor and Neubig, 2005).

The RGS protein family is composed of $>30$ proteins that differ in structure, function, and tissue/cellular localization (Traynor and Neubig, 2005). RGS proteins are potential targets for new therapeutic drugs for pain based on their ability to regulate $\mu$-opioid receptors. Several of the RGS family members are involved in regulation of $\mu$-opioid receptors, including RGS4 (Garzón et al., 2005a; Roman et al., 2007; Leontiadis et al., 2009; Santhappan et al., 2015), RGS9-2 (Psifogeorgou et al., 2007; Papachatzaki et al., 2011; Gaspari et al., 2017), RGS19 (Wang and Traynor, 2013), and RGSz (Garzón et al., 2005c; Gaspari et al., 2018). These proteins regulate $\mu$-opioid receptor signaling to effectors, including adenylyl cyclase, calcium channels, and mitogen-activated protein kinase (Clark et al., 2003; Psifogeorgou et al., 2007), as well as $\mu$-opioid receptor-mediated behaviors (Zachariou et al., 2003; Traynor et al., 2009; Han et al., 2010; Gaspari et al., 2014). However, redundancy and tissue expression overlap of the RGS family of proteins is a problem for interpreting knock-down or knock-out strategies for specific RGS proteins. To deal with this concern, knock-in transgenic mice were generated with a mutation in G $\alpha$ o (G184S) that is insensitive to all RGS regulation (Goldenstein et al., 2009). G $\alpha$ o subunits mediate $\mu$-opioid receptor signaling to several effectors (Clark et al., 2003), as well as morphine- and methadone-induced antinociception (Lamberts et al., 2011).

Consistent with previous studies showing that RGS proteins are negative regulators of $\mu$-opioid receptor signaling (Clark et al., 2003, 2004; Zachariou et al., 2003), opioid agonist inhibition of evoked GABA release in the supraspinal ventrolateral periaqueductal gray (vlPAG) is increased in the RGS-insensitive mutant mice, along with an increased potency of morphine in the supraspinally mediated hot-plate test (Lamberts et al., 2013). In contrast, morphine potency is decreased in the spinally mediated tail withdrawal test (Lamberts et al., 2013). This suggests that RGS proteins are positive regulators of some $\mu$-opioid receptor effectors. Indeed, knockout of RGS9 compromised opioidinduced hyperpolarization in the dorsal horn of the spinal cord (Papachatzaki et al., 2011), presumably mediated by G-proteingated inwardly rectifying $\mathrm{K}^{+}$channels (GIRKs; Marker et al., 2004, 2005). Since $\mu$-opioid receptors hyperpolarize neurons via the activation of GIRK channels in the vlPAG (Chieng and Christie, 1996; Osborne et al., 1996; Ingram et al., 2008), we examined whether RGS proteins have different actions depending on the effector system. We hypothesized that $\mu$-opioid receptor signaling to GIRK channels in the vlPAG would be compromised in the RGS-insensitive mice.

\section{Materials and Methods}

Subjects. Male and female mice heterozygous (Het) for RGS insensitivity (Goldenstein et al., 2009) and littermate wild-type (WT) 129S1/SvImJ male and female mice were used for all experiments comparing WT (The Jackson Laboratory) and Het mice. Mice were obtained from WT and Het breeding pairs to control for genetic background. Homozygous knock-in mice die before birth, so WT mice were compared with Het mice. The Het mice tended to be smaller, so experimenters in behavioral studies were not blind to genotype. Studies using G-protein peptide inhibitors used WT mice (The Jackson Laboratory). Mice were group housed with unlimited access to food and water. Lights were maintained on a $12 \mathrm{~h} \mathrm{light/dark} \mathrm{cycle} \mathrm{(lights} \mathrm{on} \mathrm{at} \mathrm{7:00} \mathrm{A.M.).} \mathrm{The} \mathrm{Institutional}$ Animal Care and Use Committee at Oregon Health \& Science University approved all electrophysiological experimental procedures. All behavioral testing was performed during the light phase, and experimental procedures were approved by the University of Michigan Institutional Animal Care. Experiments were conducted in accordance with the United States National Research Council Guide for the Care and Use of Laboratory Animals (National Research Council, 2011).

Electrophysiological recordings. Mice (postnatal day $>25$ ) were anesthetized with isoflurane, and brains were removed and placed into artificial CSF (ACSF) containing the following (in $\mathrm{mm}$ ): $126 \mathrm{NaCl}, 21.4$ $\mathrm{NaHCO}_{3}, 11.1$ dextrose, $2.5 \mathrm{KCl}, 2.4 \mathrm{CaCl}_{2}, 1.2 \mathrm{MgCl}_{2}$, and 1.2 $\mathrm{NaH}_{2} \mathrm{PO}_{4}, \mathrm{pH} 7.35$, and equilibrated with $95 \% \mathrm{O}_{2} / 5 \% \mathrm{CO}_{2}$. Brain slices containing the vlPAG were cut with a vibratome $(180-220 \mu \mathrm{m}$ thick $)$ and placed in a holding chamber with oxygenated ACSF maintained at $\sim 32^{\circ} \mathrm{C}$ until placed into a recording chamber. In experiments using myristoylated $\mathrm{G} \alpha \mathrm{o}$ and $\mathrm{G} \alpha \mathrm{i}$ peptide inhibitors, slices were incubated for at least $30 \mathrm{~min}$ in ACSF plus inhibitor before recording. Recordings were made with electrodes pulled to $2-3 \mathrm{M} \Omega$ resistance with internal solutions consisting of the following (in $\mathrm{mm}$ ): either 138 potassium methylsulfate or 138 potassium gluconate, $10 \mathrm{HEPES}, 10 \mathrm{KCl}, 1 \mathrm{MgCl}_{2}, 1$ EGTA, 0.3 $\mathrm{CaCl}_{2}, 4 \mathrm{MgATP}$, and $3 \mathrm{NaGTP}, \mathrm{pH}$ 7.4. Junction potentials of $15 \mathrm{mV}$ were corrected at the beginning of the experiments. Access resistance was monitored throughout the experiments. Neurons were voltage-clamped at $-70 \mathrm{mV}$. Data were collected with Axopatch 200B Microelectrode Amplifier (Molecular Devices) at $5 \mathrm{kHz}$ and low-pass filtered at $2 \mathrm{kHz}$. Currents were digitized with InstruTECH ITC-18 (HEKA), collected via AxoGraph Data Acquisition software and analyzed using AxoGraph (Axograph Scientific). Single mice were sacrificed without an opportunity to compare size, so electrophysiological studies were performed blind to genotype. Genotyping of mice was performed from tail snips that were taken after mice were killed. In experiments using $\mathrm{G} \alpha \mathrm{o}$ and $\mathrm{G} \alpha \mathrm{i}$ inhibitor peptides, all mice were WT, but the analyses of peak drug effects were measured blind to condition.

Behavioral tests. Experiments were conducted using adult mice between 10 and 20 weeks of age. Supraspinal antinociception was evaluated in the hot-plate test, and spinal antinociception was measured in the warm-water tail withdrawal assay using a cumulative dosing procedure, as previously described (Lamberts et al., 2011). Briefly, mice were administered increasing doses of baclofen (intraperitoneally) in $30 \mathrm{~min}$ intervals, and latency was evaluated $30 \mathrm{~min}$ following each injection. In the hot-plate test, mice were placed on a hot-plate analgesia meter (Columbus Instruments) maintained at $52.0 \pm 0.2^{\circ} \mathrm{C}$, and the latency to lick forepaws or to jump was measured with a cutoff time of $60 \mathrm{~s}$ to prevent tissue damage. In the tail withdrawal test, mice were lightly restrained and the distal tip of the tail of the mouse was placed in a water bath (Fisher Scientific) maintained at $50.0 \pm 0.5^{\circ} \mathrm{C}$. The latency to tail flick was measured with a cutoff time of $20 \mathrm{~s}$.

Locomotor activity was measured using a two-compartment placeconditioning apparatus (Med Associates). The compartments were similar in dimension $(8 \times 5 \times 5$ inches) but differed in wall color and floor texture (compartment 1, black walls with rod flooring; compartment 2 , white walls with mesh flooring). Infrared photobeam sensors lining the bottom of two parallel walls recorded the beam breaks generated by mouse locomotion. Activity counts were recorded as the total number of beam breaks within $30 \mathrm{~min}$, following a $30 \mathrm{~min}$ treatment with baclofen (3.2 or $10 \mathrm{mg} / \mathrm{kg}$ ) or vehicle (sterile water). An equal number of male and 
A

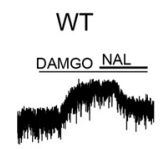

$\underset{1 \mathrm{ma}}{20 \mathrm{~m}}$

C

DAMGO $5 \mu \mathrm{M}$

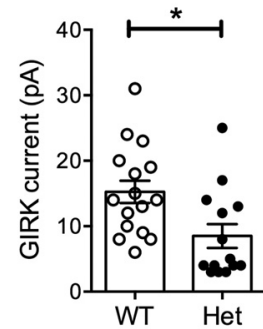

E Fentanyl $1 \mu \mathrm{M}$

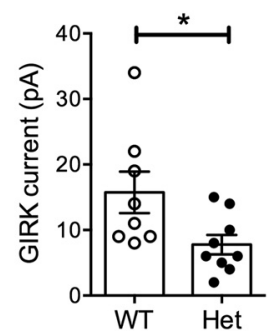

B

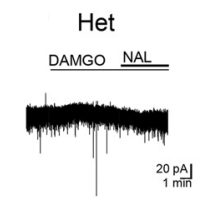

D DAMGO in LC

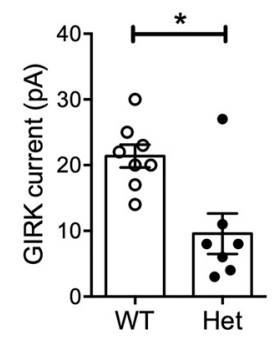

$\mathbf{F}$

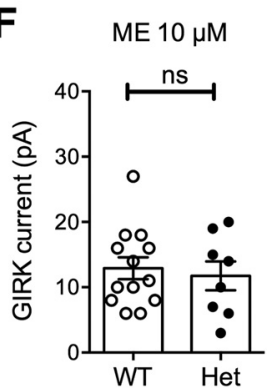

Figure 1. Opioid agonist activation of GIRK channels is differentially affected in the RGSinsensitive mice. $A$, Representative trace of a recording from a vIPAG neuron from a WT mouse where the selective opioid agonist DAMGO $(5 \mu \mathrm{M})$ elicited an outward current that was reversed by the $\mu$-opioid receptor antagonist naloxone (NAL; $10 \mu \mathrm{M}) . B$, Representative trace from a VIPAG neuron from an RGS-insensitive Het mouse. $C$, Compiled data for DAMGO in WT and Het mice showing reduced GIRK currents in Het mice (Mann-Whitney $U_{(313,152)}=47,{ }^{*} p=0.006$ ). $D$, Compiled data from recordings in $L C$ neurons showing decreased currents in Het mice (Mann-Whitney $U_{(85,35)}=7,{ }^{*} p=0.01$ ). $E$, Compiled data for fentanyl $(1 \mu \mathrm{M}$ ) activation of GIRK currents in vIPAG neurons, also with reduced GIRK currents in Het mice (Mann-Whitney $\left.U_{(95,58)}=13,{ }^{*} p=0.03\right) . F$, ME-induced GIRK currents were of similar amplitude in WT and Het mice (Mann-Whitney $\left.U_{(148,84)}=48, p=0.76\right)$.

female mice were placed in either compartment per treatment. Compartments were cleaned between tests.

Reagents. [D-Ala(2),N-Me-Phe(4),Gly(5)-ol]-enkephalin (DAMGO), $\left[\mathrm{Met}^{5}\right]$-enkephalin acetate salt hydrate (ME) and fentanyl citrate salt (fentanyl) were obtained from Sigma-Aldrich, and $(R, S)$-baclofen and CGP 55845 hydrochloride were purchased from Abcam. Myristoylated G-protein peptide inhibitors were synthesized by GenScript, as follows: G $\alpha \mathrm{o}_{1}$ (MGIANNLRGCGLY), G $\alpha \mathrm{i}_{1 / 2}$ (MGIKNNLKDCGLP), and $\mathrm{G} \alpha \mathrm{i}_{3}$ (MGIKNNLKECGLT) according to sequences for mini-gene vectors designed by the Hamm laboratory (Vanderbilt University Medical Center, Nashville TN; Gilchrist et al., 2002). We were unable to obtain the peptide for $\mathrm{GaO}_{2}$ at sufficient purity to use in slice experiments. The G $\alpha \mathrm{i}$ inhibitors were combined in experiments.

Statistical analyses. All data are expressed as mean \pm SEM. Data were analyzed with Prism 6 (GraphPad Software). Each electrophysiological recording from a single neuron is treated as an individual observation; however, all datasets contain recordings from at least three separate animals. Drug effects were reversed by specific antagonists, and peak drug effects were measured as an increase in current from the average of baseline and washout or the presence of antagonists. A cell was considered a nonresponder if there was no change in the current induced by the agonist during washout of the agonist or in the presence of the antagonist. Behavioral studies used 12 mice per group distributed evenly between males and females. Differences between groups were assessed using the Mann-Whitney $U$ nonparametric test or ANOVA when appropriate (significance is denoted as ${ }^{*} p<0.05$ ).

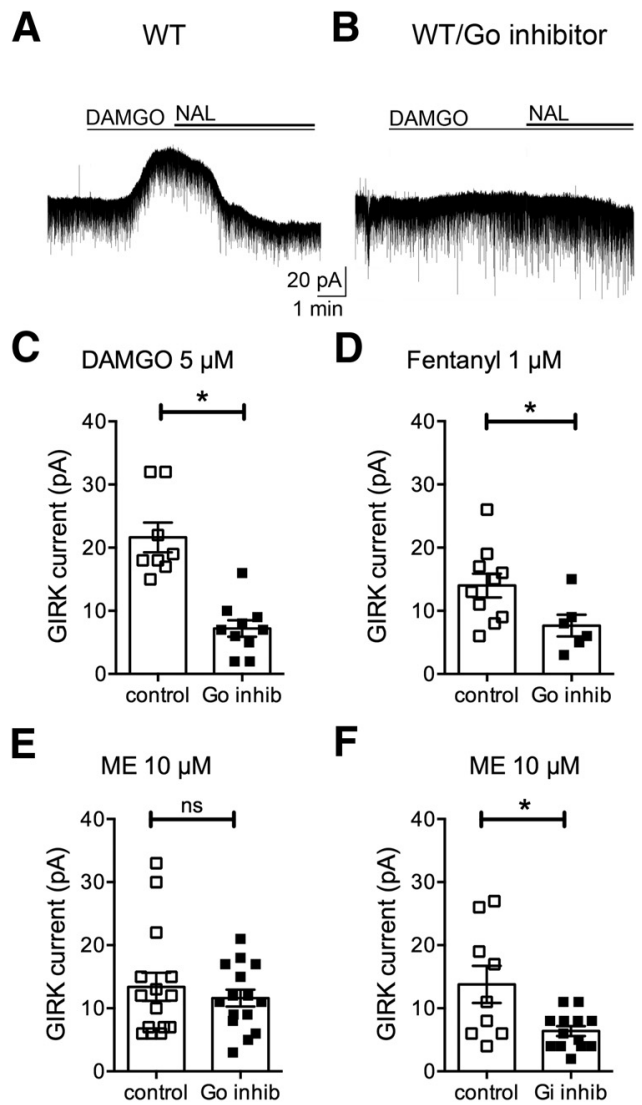

Figure 2. Specific inhibitor peptides for $G \alpha$ proteins reduce opioid-induced GIRK currents in an agonist-dependent manner. $\boldsymbol{A}$, Representative trace of a vIPAG neuron recording from a WT mouse showing the outward current in response to DAMGO $(5 \mu \mathrm{M})$ that is reversed by naloxone (NAL; $10 \mu \mathrm{M})$. B, DAMG0-mediated GIRK current from a vIPAG neuron from a WT mouse in the presence of the $G \alpha 0_{1}$ inhibitor peptide $(5 \mu \mathrm{M})$. C, Compiled data showing $G \alpha 0$ inhibitor peptide $(5 \mu \mathrm{M})$ inhibition of DAMG0-mediated GIRK currents (Mann-Whitney $U_{(115,56)}=1,{ }^{*} p<$ 0.0001). D, Compiled data showing $G \alpha 0$ inhibitor peptide $(5 \mu \mathrm{M})$ inhibition of fentanylmediated GIRK currents (Mann-Whitney $U_{(105,31)}=10,{ }^{*} p=0.03$ ). E, Compiled data showing that the $G \alpha 0$ inhibitor peptide $(5 \mu \mathrm{M})$ does not affect GIRK currents mediated by ME (MannWhitney $\left.U_{(237,229)}=109, p=0.88\right)$. $\boldsymbol{F}_{\text {, The }} \mathrm{G} \alpha \mathrm{i}_{1-3}$ inhibitor peptide $(5 \mu \mathrm{M})$ reduces MEinduced GIRK currents (Mann-Whitney $U_{(134,119)}=28,{ }^{*} p=0.04$ ).

\section{Results}

RGS proteins are known to negatively regulate GPCR signaling by increasing the hydrolysis of GTP to terminate G-protein signaling. $\mu$-Opioid receptors inhibit presynaptic GABA release in the vlPAG (Chieng and Christie, 1994; Vaughan and Christie, 1997; Vaughan et al., 1997b; Ingram et al., 1998). We had previously observed in RGS-insensitive mice that opioid inhibition of GABA release was increased (Lamberts et al., 2013), which is consistent with negative regulation of $\mu$-opioid receptor signaling. $\mu$-Opioid receptors are $\mathrm{G}_{\mathrm{i} / \mathrm{o}}$-coupled GPCRs that also couple to GIRK channels in the vlPAG with $\mu$-opioid receptor agonists activating GIRKs in $\sim 40 \%$ of vlPAG neurons (Osborne et al., 1996; Ingram et al., 2008). Interestingly, DAMGO-mediated GIRK currents in vlPAG neurons were reduced in the RGSinsensitive Het mice ( 14 responders/27 cells) compared with WT mice ( 16 responders/30 cells; Fig. $1 A-C$ ). A response was defined as an outward current in response to agonist application that reversed during the washout of agonist or in the presence of antagonist. Neurons that did not respond with any outward currents were not included in the analyses of mean amplitude because a lack of response may be due to the loss of RGS function or 
no $\mu$-opioid receptor coupling to GIRK channels in an individual neuron. Similar results were observed in locus coeruleus (LC) neurons, which express $\mu$-opioid receptors in all neurons (Fig. $1 D$ ), confirming that small currents in the vlPAG of RGS-insensitive Het mice were actually measured in $\mu$-opioid receptor-expressing neurons. Recordings were made from male and female WT and Het mice, but we observed no difference in the amplitude of DAMGO $(5 \mu \mathrm{M})$-induced GIRK currents (two-way ANOVA; main effect of sex: $\left.F_{(1,23)}=0.32 ; p=0.58\right)$. Thus, male and female responses are grouped in Figure 1. These results indicate that $\mu$-opioid receptor coupling to GIRK channels is compromised in the RGS-insensitive G $\alpha$ o mutant mice.

To further characterize $\mu$-opioid receptor agonist activation of GIRK channels in the RGS-insensitive mice, we used the selective agonist fentanyl and the nonselective $\mu$-opioid receptor and $\delta$-opioid receptor agonist ME. Fentanyl (1 $\mu \mathrm{M})$ induced currents were also smaller in the mutant mice in a similar proportion of neurons (Het mice, 9 responders/19 recordings; WT mice, 8 responders $/ 20$ recordings; Fig. 1E). In contrast, ME (10 $\mu \mathrm{M})$-induced currents were not reduced in the RGS-insensitive mice (Het mice, 8 responders/14 cells; WT mice, 13 responders/19 cells; Fig. $1 F$ ). This observation was not a result of $\delta$-opioid receptor activation in the vlPAG because the selective $\delta$-opioid receptor antagonist naltrindole $(100 \mathrm{~nm})$ did not significantly reduce the $\mathrm{ME}$-induced current $\mathrm{ME}$ alone, $12 \pm 4 \mathrm{pA} ; \mathrm{ME}+$ naltrindole, $11 \pm 3 \mathrm{pA} ; n=5$ ).

The RGS-insensitive mice have a mutation in G $\alpha$ o that disrupts the binding of RGS proteins to G $\alpha$ o. To further confirm that the observed effects were due to $\mathrm{G} \alpha \mathrm{O}$ signaling, we used a myristoylated peptide inhibitor synthesized according to mini-gene sequences designed by the Hamm laboratory (Gilchrist et al., 1999, 2002). These peptides bind to the active site on G $\alpha$ o subunits blocking their activation by GPCRs. The $\mathrm{G} \alpha \mathrm{o}_{1}$ inhibitor peptide ( $5 \mu \mathrm{M}$ ) blocked DAMGO-mediated GIRK currents (Fig. $2 A-C$ ). Inhibition of $\mathrm{G} \alpha \mathrm{O}_{1}$ also reduced the GIRK currents induced by fentanyl ( $1 \mu \mathrm{M}$; Fig. 2D). Because the peptide sequence to ${\mathrm{G} \alpha \mathrm{O}_{2}}_{2}$ could not be synthesized, it is not clear whether the residual current is due to the presence of uninhibited $\mathrm{G} \alpha \mathrm{O}_{2}$ or to incomplete penetration of the $\mathrm{G}_{\alpha} \mathrm{o}_{1}$ inhibitor peptide into the slices and incomplete blockade of the $\mathrm{G}_{\alpha \mathrm{O}_{1}}$ proteins. Consistent with the results in the RGSinsensitive mice, the $\mathrm{G}_{\alpha} \mathrm{O}_{1}$ inhibitor peptide had no effect on ME-induced GIRK currents (Fig. 2E). This result also provided a control for the possibility that the myristoylated peptides inhibited $\mu$-opioid receptor activation of GIRK channels through a nonselective action. Since $\mu$-opioid receptors couple to both $\mathrm{G} \alpha \mathrm{i}$ and $\mathrm{G} \alpha$ o proteins, we tested the possibility that ME preferentially

E

\section{WT/Go inhibitor}

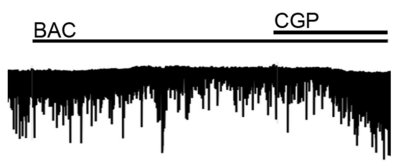

D

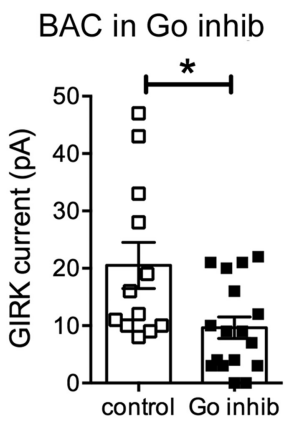

BAC in Gi inhib

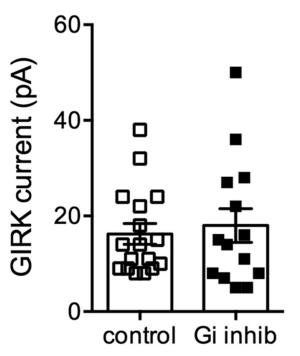

Warm-water tail withdrawal test

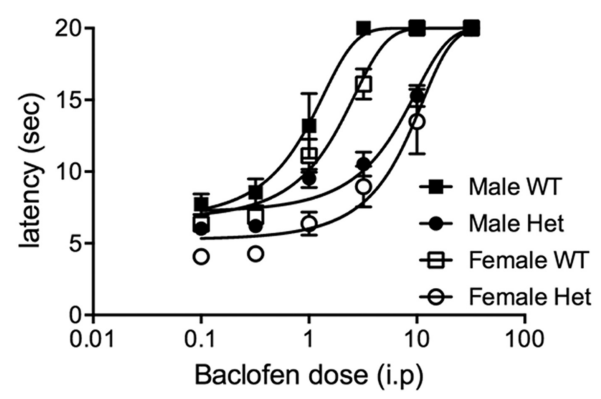

Figure 3. $G A B A_{B}$ receptor agonist baclofen uses $G \alpha 0$ in vIPAG neurons, and baclofen-mediated antinociception is diminished in $\left.=148,{ }^{*} p=0.01\right)$. C, Representative trace showing reduced baclofen-mediated current in the presence of the $G \alpha 01$ currents (Mann-Whitney $\left.U_{(332,263)}=142, p=0.99\right)$. $\boldsymbol{E}$, Baclofen dose-response curve for antinociception using the warm-water tail withdrawal test showing a significant shift to the right in the RGS-insensitive Het male mice $\left(\mathrm{EC}_{50}=3.1 \mathrm{mg} / \mathrm{kg} ; 95 \% \mathrm{Cl}\right.$, $2.3-3.9 \mathrm{mg} / \mathrm{kg})$ and female mice $\left(\mathrm{EC}_{50}=5.5 \mathrm{mg} / \mathrm{kg} ; 95 \% \mathrm{Cl}, 4.7-6.4 \mathrm{mg} / \mathrm{kg}\right)$ compared with WT male mice $\left(\mathrm{EC}_{50}=0.50 \mathrm{mg} / \mathrm{kg} ;\right.$ $95 \%(\mathrm{Cl}, 0.4-0.6 \mathrm{mg} / \mathrm{kg})$ and female mice ( $\mathrm{EC}_{50}=1.0 \mathrm{mg} / \mathrm{kg} ; 95 \%\left(\mathrm{Cl}, 0.7-1.2 \mathrm{mg} / \mathrm{kg} ; F_{(3,116)}=63, p<0.0001, n=6 /\right.$ group $)$. Measurements were made $30 \mathrm{~min}$ after each baclofen dose. inhib, inhibitor.

activates GIRK via G $\alpha$ i subunits. Myristoylated $\mathrm{G} \alpha \mathrm{i}_{1-3}$ inhibitor peptides significantly reduced the ME-induced GIRK currents (Fig. $2 F$ ), confirming that ME preferentially signals to GIRK through $\mathrm{G} \alpha \mathrm{i}$ and providing an explanation for the differences between agonists in slices from the RGS-insensitive Het mice.

$\mathrm{GABA}_{\mathrm{B}}$ receptors are also coupled to GIRK channels, and the $\mathrm{GABA}_{\mathrm{B}}$ agonist baclofen $(20 \mu \mathrm{M})$ elicits a GIRK current in most vlPAG neurons (Fig. 3A; Chieng and Christie, 1995; Vaughan et al., 1997a). Thus, baclofen was tested in recordings as a control for neuron viability, especially in neurons that did not respond to opioid agonists. The baclofen-mediated currents were reversed by the selective $\mathrm{GABA}_{\mathrm{B}}$ antagonist CGP55845 $(1 \mu \mathrm{M})$ and were reduced in Het mice (Fig. $3 B$ ). Baclofen-induced GIRK currents were similar in male and female mice (two-way ANOVA; main effect of sex: $\left.F_{(1,48)}=0.11 ; p=0.74\right)$, so responses were combined. We further tested baclofen with the $\mathrm{G} \mathrm{O}_{1}$ inhibitor peptide and the $\mathrm{G} \alpha \mathrm{i}_{1-3}$ inhibitor peptides (Fig. 3C,D). Baclofen-induced GIRK cur- 
A

Hot plate test

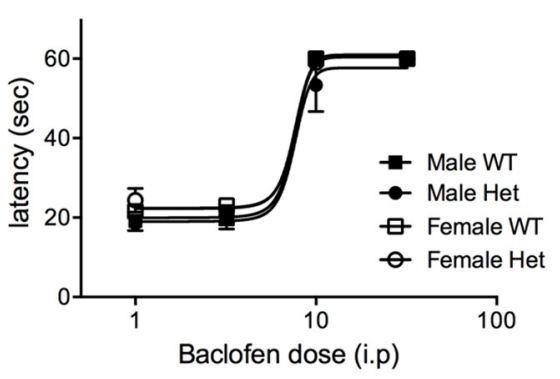

C

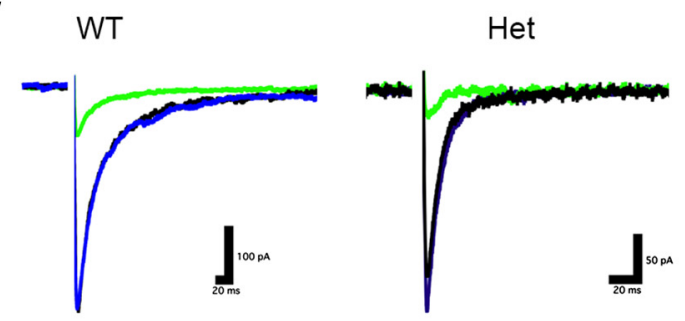

B

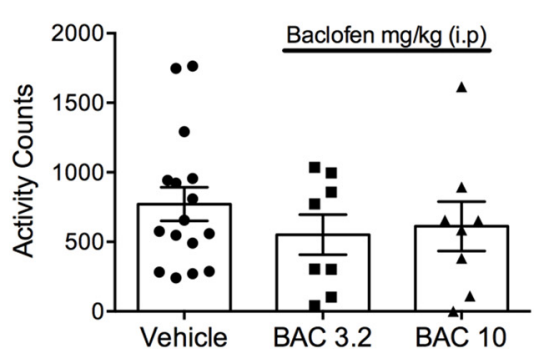

D Baclofen $20 \mu \mathrm{M}$

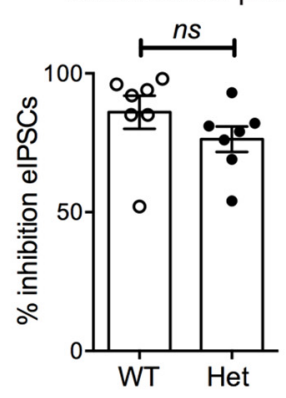

Figure 4. Baclofen (BAC) dose-response curve on the supraspinally mediated hot-plate test is similar in both genotypes. $\boldsymbol{A}$, Dose-response curve for baclofen-mediated antinociception using the hot-plate test showing no difference between genotypes or sex ( $n=6$ /group). $\boldsymbol{B}$, Baclofen-treated WT mice showed no loss of locomotor activity in a novel environment. Locomotor activity was recorded for $30 \mathrm{~min}$, following a $30 \mathrm{~min}$ treatment with baclofen ( 3.2 or $10 \mathrm{mg} / \mathrm{kg} ; n=8 /$ dose) or vehicle (V, water; $n=18$; $\left.F_{(2,29)}=0.68, p=0.52\right)$. Each bar \pm SEM represents an equal number of male and female mice. $C$, Representative evoked IPSCS showing inhibition by baclofen ( $20 \mu \mathrm{M}$, green traces) compared with control (blue traces) and the GABA antagonist CGP55845 ( $1 \mu \mathrm{m}$; black traces) in recordings from WT and Het mice. D, Summary data for the percentage inhibition showing no significant difference between genotypes (Mann-Whitney $U_{(67,38)}=10, p=0.07$ ).

rents were reduced in the presence of the $\mathrm{G} \alpha \mathrm{O}_{1}$ inhibitor peptide but were unaffected by $\mathrm{G} \alpha \mathrm{i}_{1-3}$ inhibitor peptides.

We previously published (Lamberts et al., 2013) data showing that morphine antinociception is enhanced in the RGSinsensitive mice when tested on the hot-plate test but is reduced when tested with the warm-water tail withdrawal test. The reduced antinociception in the warm-water tail withdrawal test was also observed for methadone (Lamberts et al., 2013), with no change in methadone antinociception in the hot-plate test. These results led to the hypothesis that different $\mu$-opioid receptor signaling pathways are critical for tests involving supraspinal (hot plate) versus spinal (warm-water tail withdrawal) circuits. Suprapinal $\mu$-opioid receptor activation results in the inhibition of GABA release in the PAG, and morphine inhibition of evoked GABA release is potentiated in the RGS-insensitive mice (Lamberts et al., 2013). In contrast, we find that morphine-induced GIRK currents are reduced in the RGS-insensitive mice (WT mice, $12 \pm 2 \mathrm{pA}$; Het mice, $6 \pm 1 \mathrm{pA}$; Mann-Whitney $U_{(59,33)}=$ $\left.5 ;{ }^{\star} p=0.01\right)$. We propose that GIRK signaling is critical for the spinally mediated warm-water tail withdrawal test. Thus, we hypothesized that $\mathrm{GABA}_{\mathrm{B}}$-mediated antinociception would also be differentially affected in the two behavior tests. Indeed, the baclofen dose-response curve was shifted to the right in the warm-water tail withdrawal test (Fig. $3 E$ ), similar to both morphine and methadone in our earlier study. In addition, both male and female mice responded with similar shifts in baclofen potency. The shift in the tail withdrawal test is consistent with our results demonstrating reduced baclofen-mediated activation of GIRK channels in the RGS-insensitive mice and the previously published decrease in opioid-induced antinociception using the tail withdrawal test in RGS-insensitive mice (Lamberts et al., 2013).

We also tested baclofen in the hotplate test and observed no change in the dose-response for baclofen-mediated antinociception (Fig. 4A), which was similar to our finding with methadone in the previous opioid behavior study. There was no change in locomotor activity with baclofen administration (Fig. 4B). We also observed no significant difference in baclofen-mediated inhibition of evoked GABA release in the WT versus Het mice (Fig. 4C,D), which is consistent with the lack of shift in the baclofen dose-response curve in the supraspinally mediated hotplate test.

\section{Discussion}

RGS proteins are widely expressed with overlapping expression patterns. The redundancy in expression has made it difficult to interpret the roles of single RGS proteins using knock-down or knock-out strategies. The knock-in mouse model that impairs the binding of RGS proteins to $\mathrm{G} \alpha$ o subunits (Goldenstein et al., 2009) exhibits no changes in $\mu$-opioid receptor binding or G-protein levels (Lamberts et al., 2013) and thus has been an advantageous model for determining the effects of RGS protein signaling on $\mu$-opioid receptor-mediated signaling pathways and behaviors. Our results using GPCR responses in vlPAG neurons from these mutant mice have determined that RGS proteins are required for optimal $\mu$-opioid receptor and $\mathrm{GABA}_{\mathrm{B}}$ receptor activation of GIRK channels in the vlPAG. In addition, we find that not all opioid ligands signal to GIRK channels via activation of $\mathrm{G} \alpha \mathrm{O}$.

\section{Role of GIRK channels in spinal antinociception}

$\mu$-Opioid receptors are expressed throughout the nervous system, and opioid drugs, such as morphine, have multiple effects throughout the neuraxis. Suprapinal $\mu$-opioid receptor modulation of antinociception is induced in the descending pain modulatory pathway from the PAG to the rostral ventromedial medulla to the spinal cord (Heinricher and Ingram, 2008). Supraspinal morphine antinociception is dependent on $\mu$-opioid receptors in the vlPAG (Yaksh et al., 1976; Renno et al., 1992; Lau and Vaughan, 2014) and $\mu$-opioid receptor-mediated inhibition of GABA release from presynaptic terminals in the vlPAG (Vaughan et al., 1997b; Lau and Vaughan, 2014). Both the RGS-insensitive mice (G $\alpha$ o mutant) and RGS9 knock-out mice display enhanced morphine supraspinal antinociception (Zachariou et al., 2003; Lamberts et al., 2013), as would be expected for RGS proteins acting as negative regulators of GPCR signaling; however, these mouse models have reduced morphine-mediated spinal antinociception (Papachatzaki et al., 2011; Lamberts et al., 2013). Although RGS proteins are negatively coupled to many effectors so that their actions to hydrolyze GTP facilitates the rapid termination of GPCR signaling, there have been reports that RGS proteins are required for GPCR signaling (Kovoor and Lester, 2002; Papachatzaki et al., 2011; Lamberts et al., 2013). These prior re- 
ports suggested that RGS proteins exert positive regulation of $\mu$-opioid receptor coupling to some effectors. Previous work with the RGS9 knock-out mice showed reduced opioid-mediated hyperpolarization of spinal neurons compared with WT mice ( $\mathrm{Pa}-$ pachatzaki et al., 2011). GIRK channels play a significant role in spinal morphine antinociception (Marker et al., 2004, 2005), so we hypothesized that $\mu$-opioid receptor coupling to GIRK channels would be compromised in the RGS-insensitive Het mice. Indeed, our results indicate that $\mu$-opioid receptor-GIRK coupling in the vlPAG and LC is reduced. In addition, GIRK coupling to $\mathrm{GABA}_{\mathrm{B}}$ receptors is compromised in the RGS-insensitive mice, but presynaptic inhibition of GABA release by the $\mathrm{GABA}_{\mathrm{B}}$ receptor agonist baclofen is unaffected. This difference was reflected in the behavior data showing that the baclofen dose-response curve is unchanged in the supraspinal hot-plate test but is shifted to the right in the spinally mediated tail withdrawal test. These results mirror our previous results with opioid inhibition of evoked IPSCs and opioid-induced antinociception in the RGSinsensitive mice (Lamberts et al., 2013). An alternative explanation for the observed differences between antinociceptive tests could be motor impairment caused by baclofen. However, we observed no significant effects of baclofen on locomotor behavior. In addition, baclofen effects on locomotor activity should have little effect on the tail withdrawal test, which is a spinal reflex, but would be expected to potentially alter complex behavioral responses in the hot-plate test. However, baclofen-mediated antinociception on the hot-plate test was similar in all groups. This agrees with earlier findings that any locomotor impairment by baclofen is dissociated from antinociceptive effects measured in the hot-plate and tail withdrawal tests (Levy and Proudfit, 1977).

\section{Heterogeneity of RGS proteins}

The reliance of $\mu$-opioid receptor-GIRK coupling on RGS binding to $\mathrm{G} \alpha \mathrm{o}$ appears to be dependent on either the location or the type of RGS protein that is expressed in certain brain areas. In contrast to the current findings, several other studies find that the disruption of components of RGS protein signaling complexes increase $\mu$-opioid receptor-GIRK coupling (i.e., are negatively coupled). The knockdown of RGS7B, a binding partner for RGS7 increases $\mu$-opioid receptor signaling to GIRK channels in the hippocampus (Zhou et al., 2012), and RGS protein inhibition increases $\mathrm{GABA}_{\mathrm{B}}$ receptor coupling to GIRK channels in dopamine neurons (Labouèbe et al., 2007), an effect shown to be mediated by RGS2. Thus, it is clear that regulation by RGS proteins on signaling pathways is dependent on the RGS-G $\alpha$ complexes that are expressed in various cell types. RGS proteins known to be expressed in the PAG include the R7 subfamily of RGS proteins (RGS6, RGS7, RGS9-2, and RGS11; López-Fando et al., 2005), RGSz (Garzón et al., 2005a,c; Gaspari et al., 2018), and RGS14 (Rodríguez-Muñoz et al., 2007). The RGS9-2 protein promotes $\mu$-opioid receptor-mediated hyperpolarization in the spinal cord, presumably through enhanced activation of GIRK channels (Papachatzaki et al., 2011), so RGS9-2 may be performing a similar role in the PAG. Indeed, RGS9-2 serves as a GAP to regulate both $\mathrm{G} \alpha \mathrm{i}$ and $\mathrm{G} \alpha \mathrm{o}$ proteins, with a preference toward G $\alpha$ o (Masuho et al., 2013). RGS7 has selective GAP activity for $\mathrm{G} \alpha \mathrm{o}$, but it was found to negatively regulate morphine antinociception (Sutton et al., 2016) and did not coimmunoprecipitate with the $\mu$-opioid receptor in PAG tissue (Garzón et al., 2005b) and thus may not be a likely candidate for $\mu$-opioid receptorGIRK coupling in the PAG. Similar increases in opioid antinociception were observed with the knockdown of other R7 subfamily members (Garzón et al., 2003) and RGSz (Garzón et al., 2005c).

\section{Role of RGS proteins in functional selectivity}

The GAP activity of RGS proteins affects maximal responses of partial agonists more than full agonists at the $\mu$-opioid receptor, as predicted by the collision-coupling model (Clark et al., 2003, 2008). This model also predicts that the potency of both partial and full agonists should be reduced to similar extents (Clark et al., 2008). $\mu$-Opioid receptor coupling to the inhibition of evoked GABA release in the vlPAG is consistent with this prediction, as $\mathrm{EC}_{50}$ values of morphine and ME were enhanced in the RGSinsensitive mice (Lamberts et al., 2013). Interestingly, we observed different results using maximal concentrations of DAMGO, fentanyl, and ME to activate $\mu$-opioid receptor coupling to GIRK channels in WT and RGS-insensitive mice. Maximal GIRK currents elicited by DAMGO and fentanyl were reduced in the Het mice, whereas ME-evoked currents were unaffected. Further experiments with selective inhibitors of $\mathrm{G} \alpha \mathrm{O}$ and $\mathrm{G} \alpha \mathrm{i}$ provided evidence that DAMGO and fentanyl selectively activate $\mathrm{G} \alpha$ o proteins, but ME uses G $\alpha$ i to couple to GIRK channels. Previous studies have shown that RGS proteins have different binding affinities for $\mathrm{G} \alpha$ subunits (Talbot et al., 2010; Masuho et al., 2013), so it is possible that different G-protein/ RGS complexes are bound in the presence of different $\mu$-opioid receptor agonists. RGS9-2 promotes $\mu$-opioid receptor coupling to $\mathrm{G} \mathrm{i}_{3}$ in the striatum in the presence of morphine, but $\mathrm{G} \alpha \mathrm{q}$ in the presence of fentanyl (Han et al., 2010; Psifogeorgou et al., 2011), and it negatively modulates morphine analgesia but positively modulates the actions of fentanyl, methadone, and oxycodone (Gaspari et al., 2017). In any case, the differential activation of $\mathrm{G} \alpha \mathrm{i}$ by the peptide $\mathrm{ME}$ versus the activation of $\mathrm{G} \alpha \mathrm{O}$ by other opioid agonists may provide a means to manipulate pathways preferentially used by endogenous $\mu$-opioid receptor ligands.

In summary, our studies using the RGS-insensitive mouse model have elucidated key aspects in RGS modulation of $\mu$-opioid receptor signaling in the vlPAG. Although RGS proteins negatively modulate $\mu$-opioid receptor inhibition of evoked GABA release (Lamberts et al., 2013), they positively modulate $\mu$-opioid receptor-GIRK coupling. In addition, RGS complexes differentially affect opioid agonists as ME-mediated GIRK currents were unaffected in the RGS-insensitive mice. This is presumably due to the preference for an ME-bound $\mu$-opioid receptor for G $\alpha$ i proteins. Further study of the role of RGS proteins in agonist functional selectivity looking at multiple signaling pathways may elucidate selective targets for manipulating biased signaling at $\mu$-opioid receptors.

\section{References}

Bohn LM, Lefkowitz RJ, Gainetdinov RR, Peppel K, Caron MG, Lin FT (1999) Enhanced morphine analgesia in mice lacking beta-arrestin 2. Science 286:2495-2498. CrossRef Medline

Chieng B, Christie MD (1996) Local opioid withdrawal in rat single periaqueductal gray neurons in vitro. J Neurosci 16:7128-7136. CrossRef Medline

Chieng B, Christie MJ (1994) Inhibition by opioids acting on mu-receptors of GABAergic and glutamatergic postsynaptic potentials in single rat periaqueductal gray neurones in vitro. Br J Pharmacol 113:303-309. CrossRef Medline

Chieng B, Christie MJ (1995) Hyperpolarization by GABAB receptor agonists in mid-brain periaqueductal gray neurones in vitro. $\mathrm{Br} \mathrm{J}$ Pharmacol 116:1583-1588. CrossRef Medline

Clark MJ, Harrison C, Zhong H, Neubig RR, Traynor JR (2003) Endogenous RGS protein action modulates mu-opioid signaling through gal- 
phao. effects on adenylyl cyclase, extracellular signal-regulated kinases, and intracellular calcium pathways. J Biol Chem 278:9418-9425. CrossRef Medline

Clark MJ, Neubig RR, Traynor JR (2004) Endogenous regulator of G protein signaling proteins suppress galphao-dependent, mu-opioid agonistmediated adenylyl cyclase supersensitization. J Pharmacol Exp Ther 310: 215-222. CrossRef Medline

Clark MJ, Linderman JJ, Traynor JR (2008) Endogenous regulators of G protein signaling differentially modulate full and partial mu-opioid agonists at adenylyl cyclase as predicted by a collision coupling model. Mol Pharmacol 73:1538-1548. CrossRef Medline

National Research Council (2011) Guide for the care and use of laboratory animals, Ed 8. Washington, DC: National Academies.

DeWire SM, Yamashita DS, Rominger DH, Liu G, Cowan CL, Graczyk TM, Chen XT, Pitis PM, Gotchev D, Yuan C, Koblish M, Lark MW, Violin JD (2013) A G protein-biased ligand at the mu-opioid receptor is potently analgesic with reduced gastrointestinal and respiratory dysfunction compared with morphine. J Pharmacol Exp Ther 344:708-717. CrossRef Medline

Garzón J, López-Fando A, Sánchez-Blázquez P (2003) The R7 subfamily of RGS proteins assists tachyphylaxis and acute tolerance at mu-opioid receptors. Neuropsychopharmacology 28:1983-1990. CrossRef Medline

Garzón J, Rodríguez-Muñoz M, Sánchez-Blázquez P (2005a) Morphine alters the selective association between mu-opioid receptors and specific RGS proteins in mouse periaqueductal gray matter. Neuropharmacology 48:853-868. CrossRef Medline

Garzón J, Rodríguez-Muñoz M, López-Fando A, Sánchez-Blázquez P (2005b) Activation of mu-opioid receptors transfers control of galpha subunits to the regulator of G-protein signaling RGS9-2: role in receptor desensitization. J Biol Chem 280:8951-8960. CrossRef Medline

Garzón J, Rodríguez-Muñoz M, López-Fando A, Sánchez-Blázquez P (2005c) The RGSZ2 protein exists in a complex with mu-opioid receptors and regulates the desensitizing capacity of gz proteins. Neuropsychopharmacology 30:1632-1648. CrossRef Medline

Gaspari S, Papachatzaki MM, Koo JW, Carr FB, Tsimpanouli ME, Stergiou E, Bagot RC, Ferguson D, Mouzon E, Chakravarty S, Deisseroth K, Lobo MK, Zachariou V (2014) Nucleus accumbens-specific interventions in RGS9-2 activity modulate responses to morphine. Neuropsychopharmacology 39:1968-1977. CrossRef Medline

Gaspari S, Cogliani V, Manouras L, Anderson EM, Mitsi V, Avrampou K, Carr FB, Zachariou V (2017) RGS9-2 modulates responses to oxycodone in pain-free and chronic pain states. Neuropsychopharmacology 42:1548-1556. CrossRef Medline

Gaspari S, Purushothaman I, Cogliani V, Sakloth F, Neve RL, Howland D, Ring RH, Ross EM, Shen L, Zachariou V (2018) Suppression of RGSz1 function optimizes the actions of opioid analgesics by mechanisms that involve the Wnt/ $\beta$-catenin pathway. Proc Natl Acad Sci U S A 115: E2085-E2094. CrossRef Medline

Gilchrist A, Bünemann M, Li A, Hosey MM, Hamm HE (1999) A dominant-negative strategy for studying roles of $G$ proteins in vivo. J Biol Chem 274:6610-6616. CrossRef Medline

Gilchrist A, Li A, Hamm HE (2002) G alpha COOH-terminal minigene vectors dissect heterotrimeric G protein signaling. Sci STKE 2002:pl1. CrossRef Medline

Goldenstein BL, Nelson BW, Xu K, Luger EJ, Pribula JA, Wald JM, O'Shea LA, Weinshenker D, Charbeneau RA, Huang X, Neubig RR, Doze VA (2009) Regulator of $\mathrm{G}$ protein signaling protein suppression of galphao proteinmediated alpha2A adrenergic receptor inhibition of mouse hippocampal CA3 epileptiform activity. Mol Pharmacol 75:1222-1230. CrossRef Medline

Han MH, Renthal W, Ring RH, Rahman Z, Psifogeorgou K, Howland D, Birnbaum S, Young K, Neve R, Nestler EJ, Zachariou V (2010) Brain region specific actions of regulator of $\mathrm{G}$ protein signaling 4 oppose morphine reward and dependence but promote analgesia. Biol Psychiatry 67:761-769. CrossRef Medline

Heinricher MM, Ingram SL (2008) The brainstem and nociceptive modulation. In: The senses: a comprehensive reference (Bushnell MC, Basbaum AI, eds), pp 593-626. San Diego CA: Academic.

Ingram SL, Vaughan CW, Bagley EE, Connor M, Christie MJ (1998) Enhanced opioid efficacy in opioid dependence is caused by an altered signal transduction pathway. J Neurosci 18:10269-10276. CrossRef Medline

Ingram SL, Macey TA, Fossum EN, Morgan MM (2008) Tolerance to re- peated morphine administration is associated with increased potency of opioid agonists. Neuropsychopharmacology 33:2494-2504. CrossRef Medline

Koblish M, Carr R 3rd, Siuda ER, Rominger DH, Gowen-MacDonald W, Cowan CL, Crombie AL, Violin JD, Lark MW (2017) TRV0109101, a G protein-biased agonist of the micro-opioid receptor, does not promote opioid-induced mechanical allodynia following chronic administration. J Pharmacol Exp Ther 362:254-262. CrossRef Medline

Kovoor A, Lester HA (2002) Gi Irks GIRKs. Neuron 33:6-8. CrossRef Medline

Labouèbe G, Lomazzi M, Cruz HG, Creton C, Luján R, Li M, Yanagawa Y, Obata K, Watanabe M, Wickman K, Boyer SB, Slesinger PA, Lüscher C (2007) RGS2 modulates coupling between GABAB receptors and GIRK channels in dopamine neurons of the ventral tegmental area. Nat Neurosci 10:1559-1568. CrossRef Medline

Lamberts JT, Jutkiewicz EM, Mortensen RM, Traynor JR (2011) mu-opioid receptor coupling to Galpha(o) plays an important role in opioid antinociception. Neuropsychopharmacology 36:2041-2053. CrossRef Medline

Lamberts JT, Smith CE, Li MH, Ingram SL, Neubig RR, Traynor JR (2013) Differential control of opioid antinociception to thermal stimuli in a knock-in mouse expressing regulator of G-protein signaling-insensitive $\mathrm{G} \alpha \alpha_{\mathrm{o}}$ protein. J Neurosci 33:4369-4377. CrossRef Medline

Lau BK, Vaughan CW (2014) Descending modulation of pain: the GABA disinhibition hypothesis of analgesia. Curr Opin Neurobiol 29:159-164. CrossRef Medline

Leontiadis LJ, Papakonstantinou MP, Georgoussi Z (2009) Regulator of G protein signaling 4 confers selectivity to specific $G$ proteins to modulate mu- and delta-opioid receptor signaling. Cell Signal 21:1218-1228. CrossRef Medline

Levy RA, Proudfit HK (1977) The analgesic action of baclofen [beta-(4chlorophenyl)-gamma-aminobutyric acid]. J Pharmacol Exp Ther 202: 437-445. Medline

López-Fando A, Rodríguez-Muñoz M, Sánchez-Blázquez P, Garzón J (2005) Expression of neural RGS-R7 and Gbeta5 proteins in response to acute and chronic morphine. Neuropsychopharmacology 30:99-110. CrossRef Medline

Manglik A, Lin H, Aryal DK, McCorvy JD, Dengler D, Corder G, Levit A, Kling RC, Bernat V, Hübner H, Huang XP, Sassano MF, Giguère PM, Löber S, Da Duan, Scherrer G, Kobilka BK, Gmeiner P, Roth BL, Shoichet BK (2016) Structure-based discovery of opioid analgesics with reduced side effects. Nature 537:185-190. CrossRef Medline

Marker CL, Stoffel M, Wickman K (2004) Spinal G-protein-gated $\mathrm{K}^{+}$channels formed by GIRK1 and GIRK2 subunits modulate thermal nociception and contribute to morphine analgesia. J Neurosci 24:2806-2812. CrossRef Medline

Marker CL, Luján R, Loh HH, Wickman K (2005) Spinal G-protein-gated potassium channels contribute in a dose-dependent manner to the analgesic effect of $\mu$ - and $\delta$ - but not $\kappa$-opioids. J Neurosci 25:3551-3559. CrossRef Medline

Masuho I, Xie K, Martemyanov KA (2013) Macromolecular composition dictates receptor and $\mathrm{G}$ protein selectivity of regulator of $\mathrm{G}$ protein signaling (RGS) 7 and 9-2 protein complexes in living cells. J Biol Chem 288:25129-25142. CrossRef Medline

Matthes HW, Maldonado R, Simonin F, Valverde O, Slowe S, Kitchen I, Befort K, Dierich A, Le Meur M, Dollé P, Tzavara E, Hanoune J, Roques BP, Kieffer BL (1996) Loss of morphine-induced analgesia, reward effect and withdrawal symptoms in mice lacking the mu-opioid-receptor gene. Nature 383:819-823. CrossRef Medline

Osborne PB, Vaughan CW, Wilson HI, Christie MJ (1996) Opioid inhibition of rat periaqueductal grey neurones with identified projections to rostral ventromedial medulla in vitro. J Physiol 490:383-389. CrossRef Medline

Papachatzaki MM, Antal Z, Terzi D, Szücs P, Zachariou V, Antal M (2011) RGS9-2 modulates nociceptive behaviour and opioid-mediated synaptic transmission in the spinal dorsal horn. Neurosci Lett 501:31-34. CrossRef Medline

Psifogeorgou K, Papakosta P, Russo SJ, Neve RL, Kardassis D, Gold SJ, Zachariou V (2007) RGS9-2 is a negative modulator of mu-opioid receptor function. J Neurochem 103:617-625. CrossRef Medline

Psifogeorgou K, Terzi D, Papachatzaki MM, Varidaki A, Ferguson D, Gold SJ, Zachariou V (2011) A unique role of RGS9-2 in the striatum as a posi- 
tive or negative regulator of opiate analgesia. J Neurosci 31:5617-5624. CrossRef Medline

Raehal KM, Walker JK, Bohn LM (2005) Morphine side effects in betaarrestin 2 knockout mice. J Pharmacol Exp Ther 314:1195-1201. CrossRef Medline

Raehal KM, Schmid CL, Groer CE, Bohn LM (2011) Functional selectivity at the mu-opioid receptor: implications for understanding opioid analgesia and tolerance. Pharmacol Rev 63:1001-1019. CrossRef Medline

Renno WM, Mullett MA, Beitz AJ (1992) Systemic morphine reduces GABA release in the lateral but not the medial portion of the midbrain periaqueductal gray of the rat. Brain Res 594:221-232. CrossRef Medline

Rodríguez-Muñoz M, de la Torre-Madrid E, Gaitán G, Sánchez-Blázquez P, Garzón J (2007) RGS14 prevents morphine from internalizing muopioid receptors in periaqueductal gray neurons. Cell Signal 19:25582571. CrossRef Medline

Roman DL, Talbot JN, Roof RA, Sunahara RK, Traynor JR, Neubig RR (2007) Identification of small-molecule inhibitors of RGS4 using a highthroughput flow cytometry protein interaction assay. Mol Pharmacol 71: 169-175. CrossRef Medline

Santhappan R, Crowder AT, Gouty S, Cox BM, Côté TE (2015) Mu opioid receptor activation enhances regulator of $\mathrm{G}$ protein signaling 4 association with the mu opioid receptor/G protein complex in a GTP-dependent manner. J Neurochem 135:76-87. CrossRef Medline

Sutton LP, Ostrovskaya O, Dao M, Xie K, Orlandi C, Smith R, Wee S, Martemyanov KA (2016) Regulator of G-protein signaling 7 regulates reward behavior by controlling opioid signaling in the striatum. Biol Psychiatry 80:235-245. CrossRef Medline

Talbot JN, Roman DL, Clark MJ, Roof RA, Tesmer JJ, Neubig RR, Traynor JR (2010) Differential modulation of mu-opioid receptor signaling to adenylyl cyclase by regulators of $G$ protein signaling proteins 4 or 8 and 7 in permeabilised C6 cells is galpha subtype dependent. J Neurochem 112: 1026-1034. CrossRef Medline
Traynor JR, Neubig RR (2005) Regulators of G protein signaling and drugs of abuse. Mol Interv 5:30-41. CrossRef Medline

Traynor JR, Terzi D, Caldarone BJ, Zachariou V (2009) RGS9-2: probing an intracellular modulator of behavior as a drug target. Trends Pharmacol Sci 30:105-111. CrossRef Medline

Vaughan CW, Christie MJ (1997) Presynaptic inhibitory action of opioids on synaptic transmission in the rat periaqueductal grey in vitro. J Physiol 498 2:463-472. Medline

Vaughan CW, Ingram SL, Christie MJ (1997a) Actions of the ORL $\mathrm{OR}_{1}$ receptor ligand nociceptin on membrane properties of rat periaqueductal gray neurons in vitro. J Neurosci 17:996-1003. CrossRef Medline

Vaughan CW, Ingram SL, Connor MA, Christie MJ (1997b) How opioids inhibit GABA-mediated neurotransmission. Nature 390:611-614. CrossRef Medline

Wang Q, Traynor JR (2013) Modulation of mu-opioid receptor signaling by RGS19 in SH-SY5Y cells. Mol Pharmacol 83:512-520. CrossRef Medline

Williams JT, Ingram SL, Henderson G, Chavkin C, von Zastrow M, Schulz S, Koch T, Evans CJ, Christie MJ (2013) Regulation of mu-opioid receptors: desensitization, phosphorylation, internalization, and tolerance. Pharmacol Rev 65:223-254. CrossRef Medline

Yaksh TL, Yeung JC, Rudy TA (1976) Systematic examination in the rat of brain sites sensitive to the direct application of morphine: observation of differential effects within the periaqueductal gray. Brain Res 114:83-103. CrossRef Medline

Zachariou V, Georgescu D, Sanchez N, Rahman Z, DiLeone R, Berton O, Neve RL, Sim-Selley LJ, Selley DE, Gold SJ, Nestler EJ (2003) Essential role for RGS9 in opiate action. Proc Natl Acad Sci U S A 100:1365613661. CrossRef Medline

Zhou H, Chisari M, Raehal KM, Kaltenbronn KM, Bohn LM, Mennerick SJ, Blumer KJ (2012) GIRK channel modulation by assembly with allosterically regulated RGS proteins. Proc Natl Acad Sci U S A 109:19977-19982. CrossRef Medline 